\title{
Effect of Small-Scale Wildfires on the Air Parameters near the Burning Centers
}

\author{
Egor Loboda ${ }^{1,2}$, Denis Kasymov ${ }^{1,2} * \mathbb{D}$, Mikhail Agafontsev ${ }^{1,2} \mathbb{D}$, Vladimir Reyno ${ }^{3}$, Yevgeniy Gordeev ${ }^{3}$, \\ Veronika Tarakanova $^{1,2}$, Pavel Martynov ${ }^{1,2}$ (D), Yuliya Loboda ${ }^{1,2}$, Konstantin Orlov ${ }^{1}$, Kirill Savin ${ }^{1}$ \\ and Andrey Dutov ${ }^{1}$
}

check for updates

Citation: Loboda, E.; Kasymov, D.; Agafontsev, M.; Reyno, V.; Gordeev,

Y.; Tarakanova, V.; Martynov, P.;

Loboda, Y.; Orlov, K.; Savin, K.; et al. Effect of Small-Scale Wildfires on the Air Parameters near the Burning Centers. Atmosphere 2021, 12, 75. https://doi.org/10.3390/ atmos12010075

Received: 9 December 2020 Accepted: 31 December 2020 Published: 6 January 2021

Publisher's Note: MDPI stays neutral with regard to jurisdictional clai$\mathrm{ms}$ in published maps and institutional affiliations.

Copyright: (C) 2021 by the authors. Licensee MDPI, Basel, Switzerland. This article is an open access article distributed under the terms and conditions of the Creative Commons Attribution (CC BY) license (https:// creativecommons.org/licenses/by/ $4.0 /)$.
1 Department of Physical and Computational Mechanics, National Research Tomsk State University, 634050 Tomsk, Russia; loboda@mail.tsu.ru (E.L.); amv@mail.tsu.ru (M.A.); veronika.tarakanova@mail.ru (V.T.); martypavel@bk.ru (P.M.); ysenchurova@yandex.ru (Y.L.); humermor@yandex.ru (K.O.); savin_kiri@yandex.ru (K.S.); andrey-dutov@mail.ru (A.D.)

2 Laboratory for Atmospheric Prediction, E. Zuev Institute of Atmospheric Optics of the Siberian Branch of the Russian Academy of Science, 634055 Tomsk, Russia

3 Laboratory of Wave Propagation, E. Zuev Institute of Atmospheric Optics of the Siberian Branch of the Russian Academy of Science, 634055 Tomsk, Russia; reyno@iao.ru (V.R.); gordeev@iao.ru (Y.G.)

* Correspondence: kdp@mail.tsu.ru

\begin{abstract}
The results of seminatural experiments on the study of steppe and field wildfires characteristic of the steppe and forest-steppe zones of Western Siberia are presented. Using infrared (IR) thermography methods, the main thermal characteristics of the fire front are derived, the flame turbulence scale is estimated, and changes in the structure function of the air refractive index are analyzed in the vicinity of a fire. The effect of a model fire on the change of meteorological parameters (wind velocity components, relative air humidity, and temperature) is ascertained. Large-scale turbulence is observed in the front of a seminatural fire, which is absent in laboratory conditions. The predominance of large-scale turbulence in a flame results in turbulization of the atmosphere in the vicinity of a combustion center. Strong heat release in the combustion zone and flame turbulence increase the vertical component of the wind velocity and produce fluctuations in the air refractive index, which is an indicator of atmospheric turbulization. This creates prerequisites for the formation of a proper wind during large fires. Variations in the gas and aerosol compositions of the atmosphere are measured in the vicinity of the experimental site.
\end{abstract}

Keywords: wildfire; atmosphere; IR thermography; combustion; turbulence

\section{Introduction}

Many wildfires (forest, steppe, and peat) occur every year in the world. An increase in temperature can result in an increase in the size of the burnt-out area, fire frequency, and the scale of the effects [1,2]. They often have grave and even catastrophic consequences [3], including not only the ravaging of biogeocenoses but also the emission of a huge amount of combustion products (gases and aerosols) into the atmosphere, which can be dispersed over a very far range [4-8]. Natural fires annually occur on five continents and are studied in different countries. For example, emissions of combustion products in the Amazon basin are considered in [9], the black carbon emission from fires in Southeast Asia is studied in [10], the results of the study of aerosol emissions in East Africa are presented in [11], and the emissions of gaseous combustion products and aerosols in Mexico are studied in [12]. In [13,14], special attention is paid to the consequences of wildfires, which manifest themselves in a global change in biocenoses on one hand and in the impact of carbon, gas, and aerosol emissions on climate change on the other hand.

Though the study of wildfires in the world began in the 20th century [15-24], the questions of the simulation of wildfire propagation, the prediction of its occurrence, and 
the assessment of its consequences are still far from even being specified, which allows us to confidently state that the study of these problems is still in its infancy. Therefore, experimental studies are carried out in the world, including seminatural studies [25-31]. They aim to study the spread of wildfires and assess their effects on the atmosphere via aerosol emissions, their effects on wind, etc. The emissions and transport of gaseous combustion products of wildfires [32-34], the atmospheric emissions of mercury from fires in eucalyptus forests [33], and the emissions of condensed combustion products and smoke and the effects of wildfires on wind speed [34] are studied in these experiments. Predictive models of fire and smoke are used to estimate the propagation of the fire front and burning products through the atmosphere. However, the accuracy of these models is questionable because of a lack of experimental data for verification. The accuracy of the assessment of smoke emission from a wildfire strongly depends on the accuracy of the parameters of the area burnt, preburned vegetation biomass, and fuel and its consumption [35-38]. Smoke dispersion is highly dependent on large-scale meteorology parameters and smoke plume height $[39,40]$. The latter is determined by fire geometry and intensity [41].

A significant release of thermal energy during fires, accompanied by turbulent processes in the burning front, obviously affects meteorological parameters, namely wind speed, induced atmospheric turbulence, and changes in air temperature and relative humidity. Variations in these air parameters directly influence the transport of gaseous combustion products, smoke, and aerosols.

In [22], a hypothesis about "own wind" formed during large-scale forest fires was suggested on the basis of mathematical simulation and observations made during experiments with wildfires. This phenomenon was considered the consequence of the release of a significant amount of thermal energy during combustion, convection, and the turbulence effect on the atmosphere in the burning front. Such aspects of the wildfire effect on the atmosphere remain blind spots because these phenomena cannot be simulated under laboratory conditions, while in situ experiments are difficult to carry out, are accompanied by a number of uncontrolled parameters, and require a set of static data.

Thus, we can state that the impact of wildfires on the environment and climate is extremely complex and multifactorial, requiring a comprehensive study with a variety of measuring equipment. There are large gaps in the studies of turbulence in the combustion zone and the formation of atmospheric turbulence in the vicinity of a fire, the effect of a fire on meteorological parameters (temperature, air humidity, wind speed, etc.), and the emission of aerosols and gases into the atmosphere during biomass burning. Since gases and aerosols are transported over considerable distances in the atmosphere, the study of this effect of fires on the atmosphere can create fundamental prerequisites for the development of essential new approaches for detecting distant fires.

In this work, we present the results of seminatural experimental studies of the propagation of the front of a steppe fire and its effect on meteorological parameters, the formation of atmospheric turbulence due to the dissipation of turbulent structures in the flame, and the emission of gaseous combustion products and aerosols. The related experimental data expand the fundamental knowledge about the effect of wildfires on changes in wind speed, air temperature, turbulence, and transport of combustion products.

\section{Experiments}

The experiment on steppe fire simulation was carried out on 4 May 2019, on the territory of the Basic Experimental Complex (BEC) of V.E. Zuev Institute of Atmospheric Optics of Siberian Branch of the Russian Academy of Science (IAO SB RAS) [42,43]. A strip $40 \mathrm{~m}$ long and $15 \mathrm{~m}$ wide was chosen as the main experimental site. Figure 1 shows a satellite image of the BEC where the experimental site and measurement equipment are marked.

To study the effect of a steppe fire on the formation of atmospheric turbulence, weather parameters were measured at altitudes of 3 and $10 \mathrm{~m}$ (points 8 and 9 in Figure 1). The air temperature, relative humidity, and pressure were collected with ultrasonic weather station 
"AMK-03". These weather stations measured the air temperature in the range from -50 to $+50{ }^{\circ} \mathrm{C}$ with an error of $\pm 0.5^{\circ} \mathrm{C}$, the vertical wind speed in the range from -15 to $+15 \mathrm{~m} / \mathrm{s}$ with an error of $\pm 0.2 \mathrm{~m} / \mathrm{s}$, the horizontal wind speed in the range $0.1-30 \mathrm{~m} / \mathrm{s}$ with an error of $0.1 \mathrm{~m} / \mathrm{s}$, the horizontal wind direction with an error of $\pm 4^{\circ}$, the relative air humidity in the range $15-100 \%$ with an error of $\pm 3 \%$, and the atmospheric pressure in the range from 693 to $1067 \mathrm{hPa}$ with an error of $\pm 1 \mathrm{hPa}$ [44]. The moisture content of green fuel (GF) was determined accurate to $0.01 \%$ with the use of an A\&D MX-50 moisture analyzer. The stock of GF at the experimental site varied within the range $0.476-0.563 \mathrm{~kg} / \mathrm{m}^{2}$.

The contactless IR thermography technique was used to study the temperature field and turbulence parameters in the flame. The temperature field at the fire front and the flame structure were controlled with an infrared camera JADE J530SB (sampling frequency is $50 \mathrm{frames} / \mathrm{s}$; the error was no higher than $0.01 \mathrm{~K}$ ) in the narrow spectral range $2.5-2.7 \mu \mathrm{m}$. The choice of the spectral range was determined by the emission spectrum of main flame combustion products [45]. Bays with chromel-alumel (XA) thermocouples type $\mathrm{K}$ with a junction diameter of $250 \mu \mathrm{m}$ were placed inside the experimental strip to correct the flame emissivity and control the propagation of the fire front (Figure 1) according to the technique used in experiments carried out in 2011 [46].

Similar experimental studies of fire front propagation and its effect on wooden fences and a peat layer were carried out at BEC in 2011 [46]. The experimental site used in 2011 is also shown in Figure 1. During experiments in 2011, the meteorological parameters were measured and the gaseous and aerosol composition of the atmosphere was estimated in the vicinity of the combustion front; these results were not included in the work [46]. Nevertheless, the analysis of the experiments of 2011 resulted in the conclusion of needing further studies on the wildfire effect on air parameters. The results of such studies are presented in this work. These results were received from a monitoring post described in [43], which allows measuring the following parameters: the concentration of $\mathrm{SO}_{2}$ in the range $0-2000 \mu \mathrm{g} / \mathrm{m}^{3}$ with an error of $25 \%$, the concentration of NO in the range $0-1000 \mu \mathrm{g} / \mathrm{m}^{3}$ with an error of $25 \%$, the concentration of $\mathrm{NO}_{2}$ in the range $0-1000 \mu \mathrm{g} / \mathrm{m}^{3}$ (error of $25 \%$ ); the concentration of $\mathrm{O}_{3}$ in the range $0-1000 \mu \mathrm{g} / \mathrm{m}^{3}(15 \%)$, the concentration of $\mathrm{H}_{2} \mathrm{~S}$ in the range $0-200 \mu \mathrm{g} / \mathrm{m}^{3}(15 \%)$, the concentration of $\mathrm{NH}_{3}$ in the range $0-1000 \mu \mathrm{g} / \mathrm{m}^{3}(15 \%)$, the concentration of $\mathrm{CO}_{2}$ in the range $0-10,000 \mathrm{ppm}(20 \%)$, the concentration of $\mathrm{CO}$ in the range $0-400 \mathrm{\mu g} / \mathrm{m}^{3}(20 \%)$, the concentration of $\mathrm{CH}_{4}$ in the range $0-5 \mathrm{ppm}(20 \%)$, and the aerosol particle size distribution in the range $0-300 \mathrm{~cm}^{-3}$ with an error of $25 \%$.

The burning front was homogeneously formed throughout the site width (Figure 2).

Small vegetation plots $2 \times 2 \mathrm{~m}$ in size were burned (point 2 in Figure 1) in additional experiments to study the effect of the fire front on the ignition of model fences made of combustible building materials. All the main parameters were controlled during the experiments. 


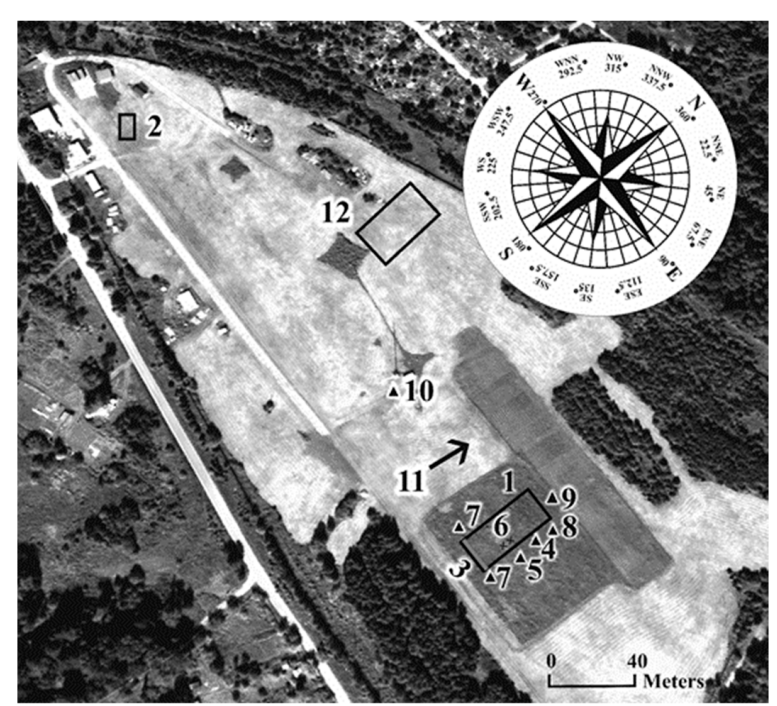

Figure 1. Satellite image of the experimental site and arrangement of measurement equipment: (1) experimental site $15 \times 40 \mathrm{~m}$ in size (2019); (2) experimental site of $2 \times 2 \mathrm{~m}$ (2019); (3) burning zone; (4) recording instruments; (5) JADE J530SB IR camera; (6) bays with thermocouples; (7) video camera; (8) AMK-03 weather station at a 3 m mast; (9) AMK-03 weather station at a 10 m mast; (10) IAO SB RAS monitoring post for greenhouse and oxidizing gases; (11) prevailing wind direction during the experiments; (12) experimental site $10 \times 50 \mathrm{~m}$ in size (2011) [46].

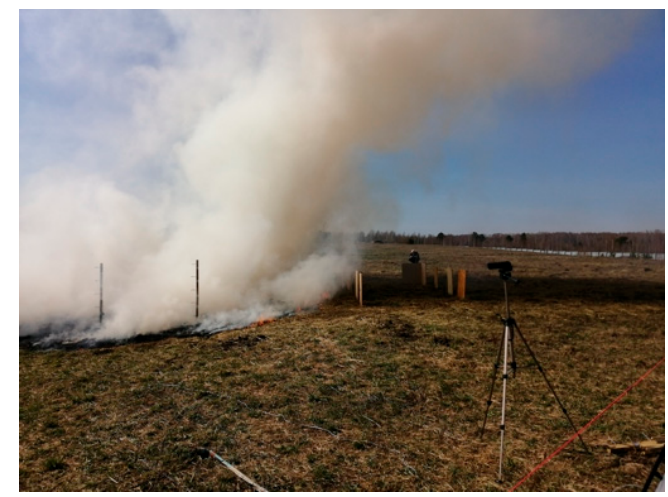

Figure 2. Burning front at the experimental site (picture was taken during the experiment).

\section{Experimental Results and Their Analysis}

During the experiment, the air temperature $T$ varied from 275 to $278 \mathrm{~K}$, the relative air humidity varied from 42 to $44 \%$, and the air pressure $P$ varied from 751 to $759 \mathrm{~mm} \mathrm{Hg}$. The wind speed changed, varying from 1 to $6 \mathrm{~m} / \mathrm{s}$; the soil temperature at a depth of $0.1 \mathrm{~m}$ was $275 \mathrm{~K}$, and the moisture content was $43 \%$. The moisture content of GF $w$ was $5.6 \%$. The stock of GF at the experimental site varied within the range $0.476-0.563 \mathrm{~kg} / \mathrm{m}^{2}$.

The temperature distribution across the fire front derived from thermocouple measurements is shown in Figure 3a. Figure 3b shows an instantaneous thermogram of the fire front and a 10-s average thermogram (Figure 3c). Analysis of the temperature distribution over the fire front points to a significantly unstable combustion process accompanied by developed turbulence in the flame. The temperature maximum over the time of the experiment, detected with use of the IR camera, reached $1200 \mathrm{~K}$ in the fire front, and the average flame height was $0.7 \mathrm{~m}$. These data are consistent with the results of experimental studies in 2009-2011 [46-49]. It should be noted that the thermocouple measurements shown in Figure $3 a$ underestimate the maxima due to the vegetation cover heterogeneity (density and moisture content) on the experimental site and the wind effect. Nevertheless, the thermocouple data were used to correct the flame emissivity in the IR measurements. 

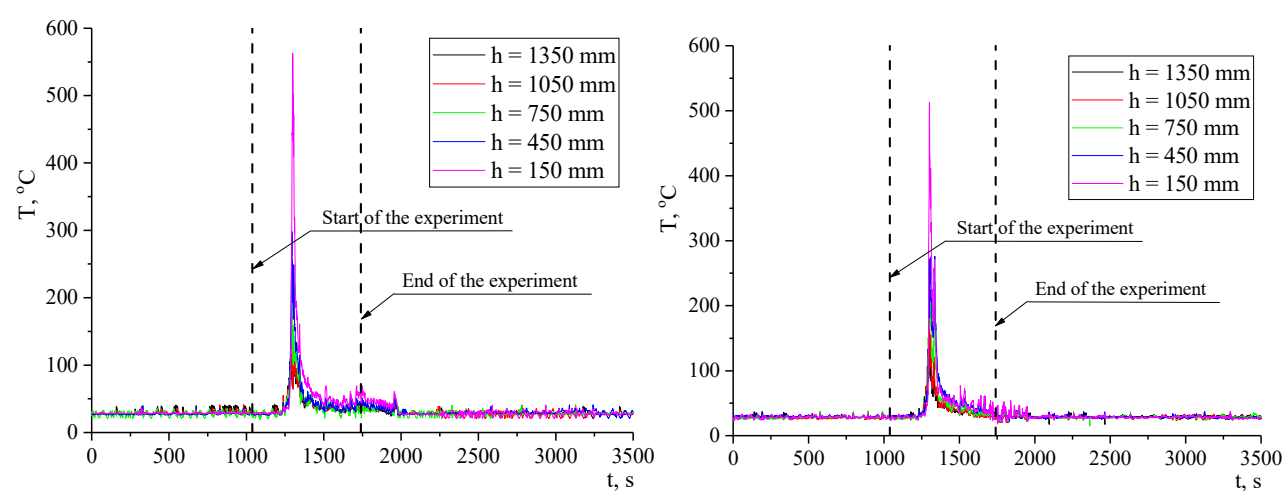

(a)

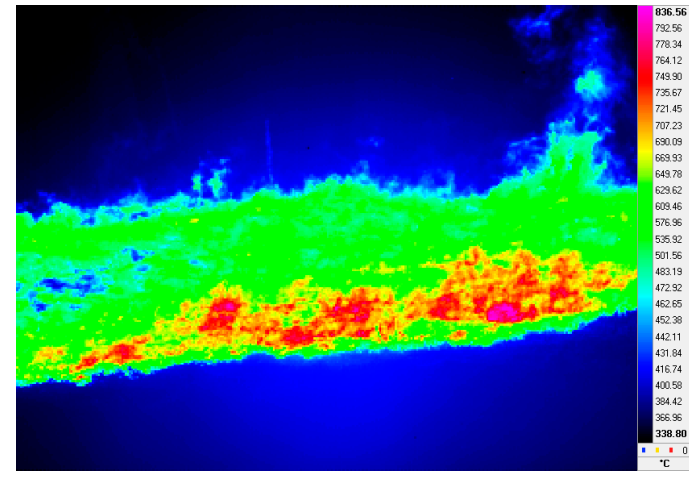

(b)

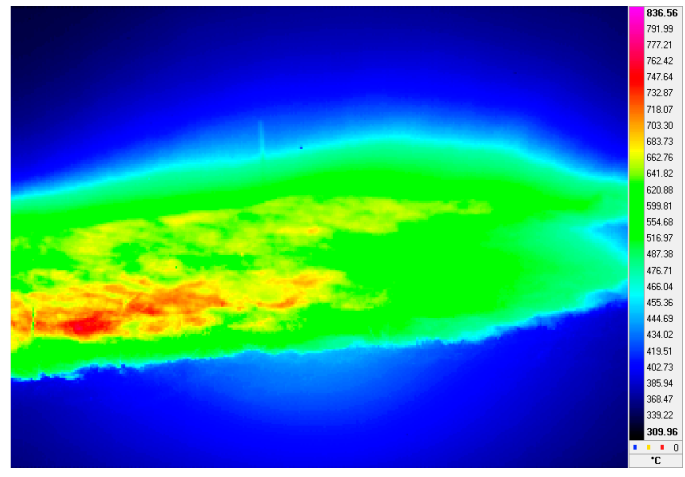

(c)

Figure 3. Temperature distribution over the fire front: (a) thermocouple measurements of the vertical temperature profile between the bays (see mark 6 on Figure 1); (b) instantaneous thermogram of the fire front; (c) fire front thermogram averaged over $10 \mathrm{~s}$.

Figure 4 shows the temperature variations in the fire front derived with the use of the technique suggested in [50] for a time interval of $6 \mathrm{~s}$. One can see characteristic frequencies in the temperature variations, which correspond to quite large turbulence scales $(b=20-64 \mathrm{~mm})$ calculated by the equation [50].

$$
b=f^{-1} \frac{\sqrt{\left\langle T^{\prime} T^{\prime}\right\rangle}}{T^{2}} \sqrt{g L}
$$

where $f$ is the characteristic frequency of fire temperature fluctuations, $1 / \mathrm{s} ; T^{\prime}$ is the pulsation of the temperature, $\mathrm{K} ; \mathrm{T}$ is the flame temperature, $\mathrm{K} ; \mathrm{g}$ is the gravity acceleration, $\mathrm{m} / \mathrm{s}^{2}$; and $L$ is the flame height, $\mathrm{m}$. We should note the prevalence of the effect of large-scale turbulence in seminatural measurements, while pulsations with frequencies of $6-8 \mathrm{~Hz}$ are sufficiently small in amplitude and do not significantly affect the flame temperature pulsations and the combustion process, in contrast to laboratory studies [50]. Special attention is paid to the dominant role of large-scale turbulence in the flame on the combustion process as a whole in [51]. 


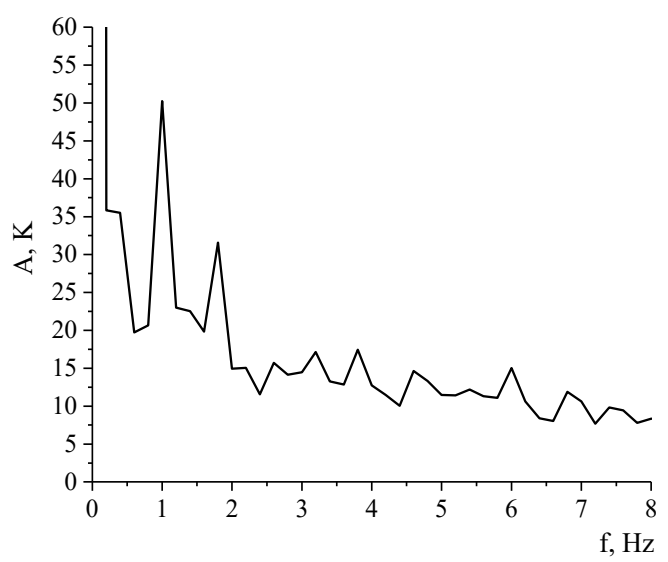

Figure 4. Temperature variation in the front of a steppe fire.

High heat release during a fire and developed large-scale turbulence in the flame due to the dissipation of turbulent structures and the emission of hot aerosol and gas components obviously affect the ambient air in the immediate vicinity of the fire front. This is confirmed by a change in meteorological parameters at weather stations 8 and 9 in Figure 1. Figure 5 shows variations in the air temperature during the experiment at altitudes of 3 and $10 \mathrm{~m}$. It should be noted that the weather station at an altitude of $10 \mathrm{~m}$ was fixed in the direction of wind and fire front propagation, while the weather station at an altitude of $3 \mathrm{~m}$ was fixed from one side of the fire front propagation and combustion product transfer direction. The results also correlate with the data [52] and the results of experiments carried out in 2011 at the IAO SB RAS post for greenhouse and oxidizing gas monitoring [43]. The mast was fixed at $35 \mathrm{~m}$ at a considerable distance from the experimental site from one side of the fire front propagation and prevailing wind direction.

A decrease in the relative air humidity and a stepwise change in the absolute air humidity (Figure 6) during the experiment should be noted. The latter was calculated by the equation $[53,54]$.

$$
a=217 \frac{e}{T_{a}}, e=\frac{r \cdot E}{100 \%}
$$

where $a$ is the absolute humidity, $\mathrm{g} / \mathrm{m}^{3} ; e$ is the partial pressure of water vapor, mbar; $T_{a}$ is the absolute temperature, $\mathrm{K} ; r$ is the relative humidity, \%; and $E$ is the saturated vapor pressure, mbar. It should be noted that the stepwise change in the absolute air humidity is connected with active moisture evaporation in the heating zone in front of the burning front and water formation in chemical reactions.

Fluctuations in the vertical component of wind velocity were also observed during the experiment due to the convection of combustion products (Figure 7). Their amplitude at an altitude of $3 \mathrm{~m}$ was obviously larger, though the weather station was fixed on one side of the fire front propagation direction. The maximum corresponds to the fire front passage in the immediate vicinity of point 8 (Figure 1). When analyzing the wind velocity, it is necessary to take into account the strong horizontal wind during the experiment, which caused a drift in and cooling of the combustion products. It is probable that the effect of convection on the increase in the vertical component of the wind velocity is more significant under a weak wind or quiet conditions. A change in wind speed during a wildfire was also noted by other authors [52]. A hypothesis about the formation of "own wind" during mass forest fires was suggested in [22]. The vertical component of wind velocity during fires was not studied; however, it has an extraordinary effect on the formation of "own wind" because it is caused by convective processes and results in a local decrease in pressure in the vicinity of a burning zone, which, in turn, intensifies the suction of a fresh portion of oxidizer into the burning zone and increases the wind velocity's horizontal component in the vicinity of the fire. When analyzing Figure 7, it is necessary to pay attention to the presence of negative values, which also exceed the values characteristic of the undisturbed 
atmosphere in the time span corresponding to a significant increase in the vertical wind component. This phenomenon is a consequence of induced turbulence due to active heat release and the dissipation of turbulent structures in the burning zone.

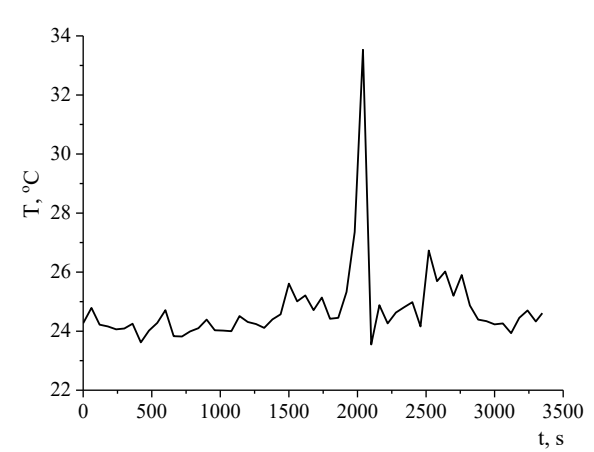

(a)

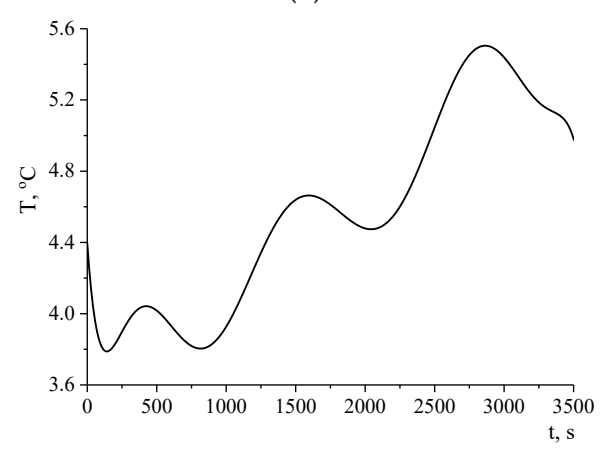

(c)

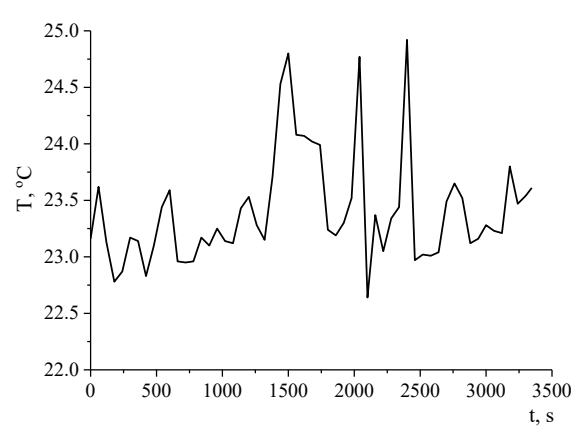

(b)

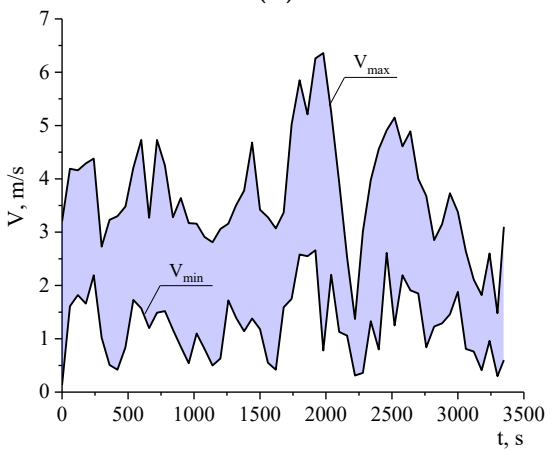

(d)

Figure 5. Variations in air temperature near the experimental site of (a) 2019, 3 m mast; (b) 2019, 10 m mast; and (c) 2011, monitoring post. (d) Variations in instantaneous horizontal wind speed [50].

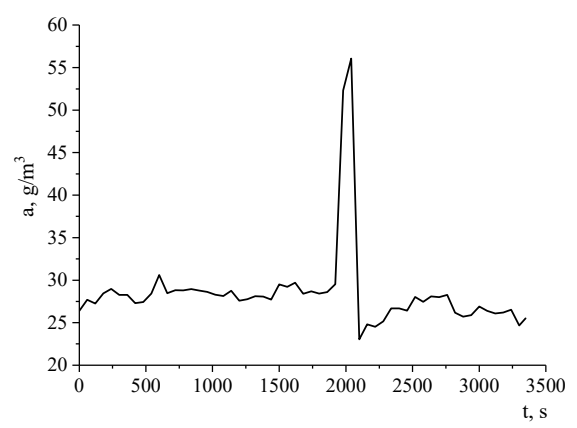

(a)

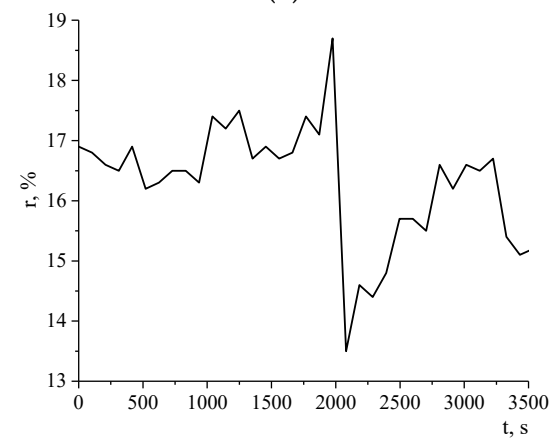

(c)

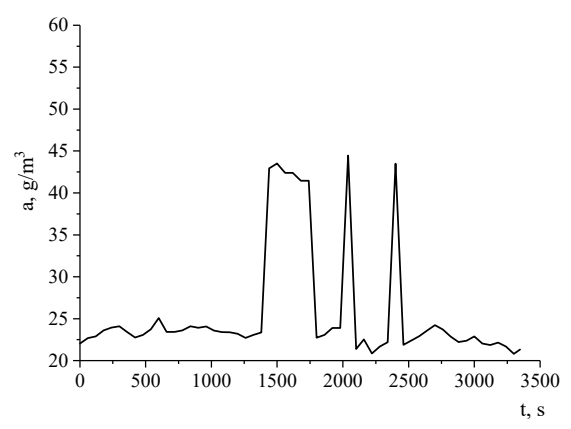

(b)

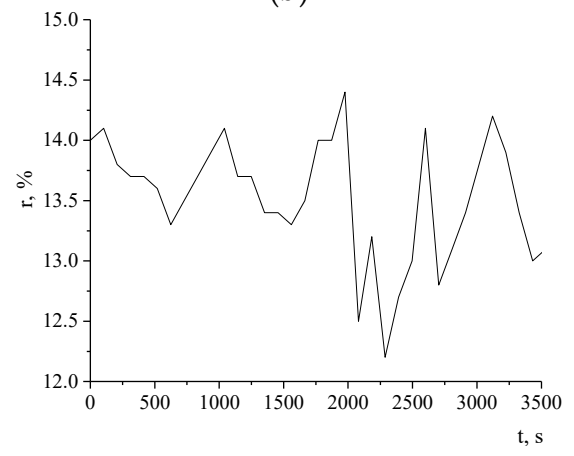

(d)

Figure 6. Variations in the $(\mathbf{a}, \mathbf{b})$ relative and $(\mathbf{c}, \mathbf{d})$ absolute air humidity during the experiment, with the mast $3 \mathrm{~m}(\mathbf{a}, \mathbf{c})$ and $10 \mathrm{~m}(\mathbf{b}, \mathbf{d})$ high. 


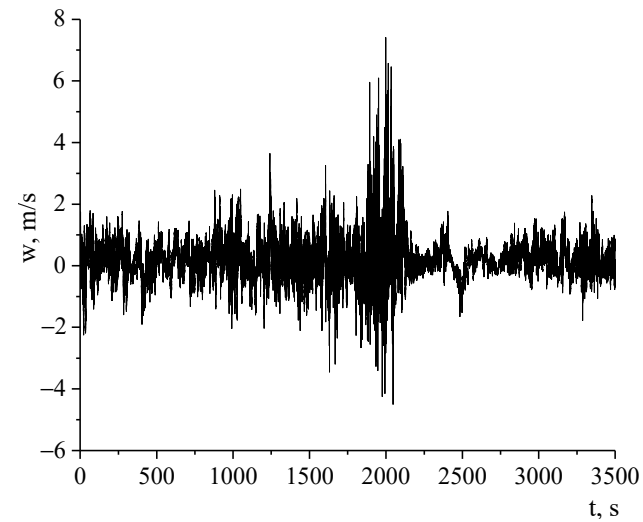

(a)

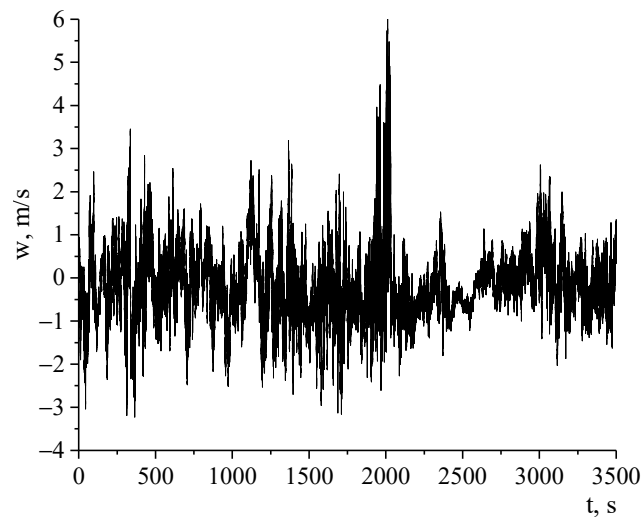

(b)

Figure 7. Variations in the vertical component of wind velocity at an altitude of (a) $3 \mathrm{~m}$ (point 8 in Figure 1) and (b) $10 \mathrm{~m}$ (point 9 in Figure 1).

Particular attention should be paid to a significant change in the fluctuations of the air refractive index $C_{n}^{2}$ (Figure 8 ), which was recorded by both measuring instruments (points 8 and 9 in Figure 1).

The AMK-03 ultrasonic weather station calculated $C_{n}^{2}$ from fluctuations in the speed of sound between ultrasonic sensors. Therefore, these fluctuations reflected turbulent processes, which ran in the air between the sensors of the weather station. Therefore, temperature fluctuations $C_{T}^{2}$ were also directly related to turbulent processes, which have been shown in [55] in the comparison between the flame thermal structure and instantaneous tracer PIV images.

During the experiment on steppe fire propagation at BEC in 2011, variations in the gas and aerosol composition of the atmosphere were also recorded. Those results were not published in [46]. Figure 9 shows variations in the concentrations of atmospheric gases, and Figure 10 shows variations in the aerosol composition depending on the particle diameter $d$. It should be noted that the variations in the gaseous and aerosol composition of the atmosphere were recorded a certain time after the start of combustion because of the relative remoteness of the monitoring post [43] and wind direction during the experiment. An increase in the methane concentration should be especially noted. The reasons for this phenomenon are unclear. However, it probably should be taken into account during mass wildfires, and its nature should be studied.

On the one hand, analysis of Figures 9 and 10 reveals a quite obvious conclusion about the release of a significant amount of aerosol particles of different sizes and oxidizing gases into the atmosphere during wildfires. Their concentrations increased 10 -fold compared to the background values. On the other hand, a decrease in the ozone concentration and an increase in the methane concentration were recorded during the experiments. These facts require further study, both experimentally and in mathematical simulations. However, it is obvious that this information can form the basis for techniques for the remote detection of wildfires. 

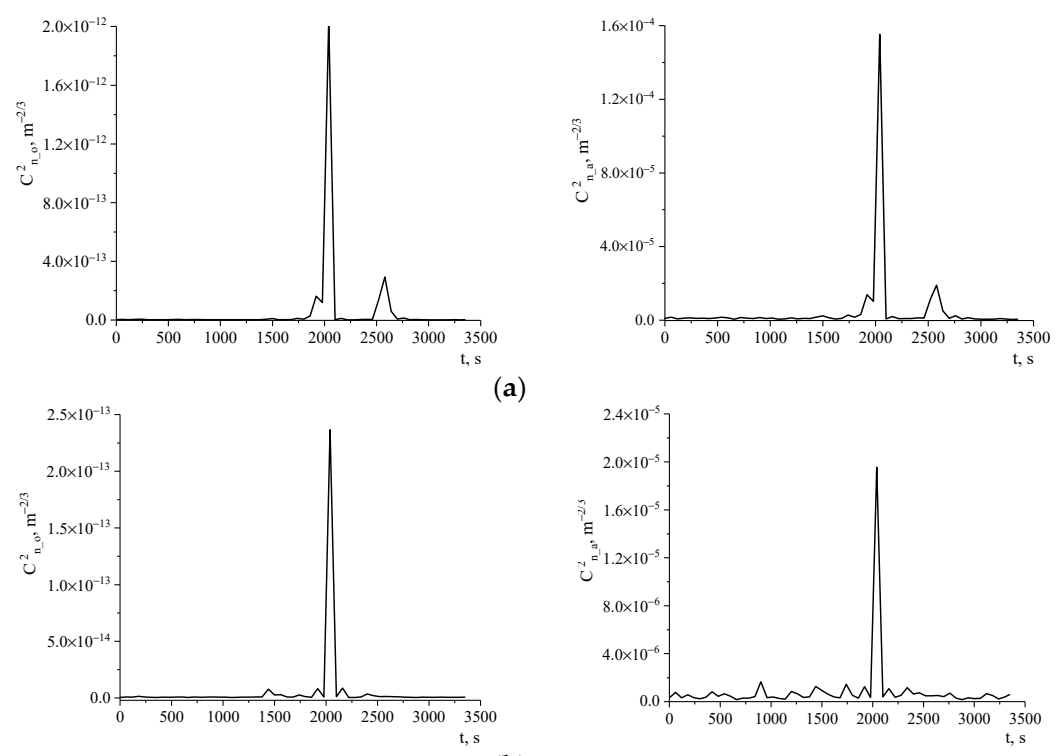

(b)

Figure 8. Changes in the fluctuations of the air refractive index $C_{n}^{2}$ : (a) data from the monitoring post at $3 \mathrm{~m}$; (b) data from the monitoring post at $10 \mathrm{~m}$.

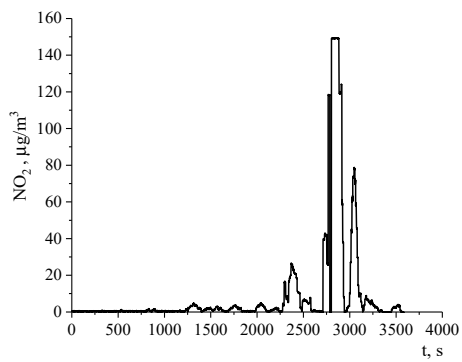

(a)

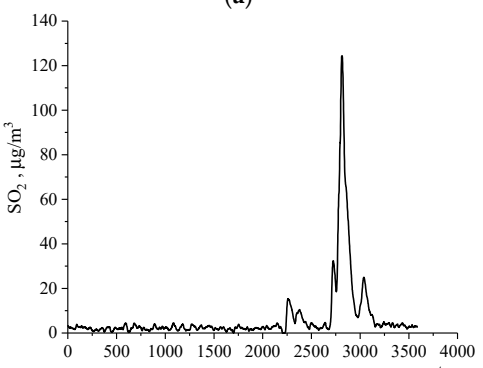

(c)

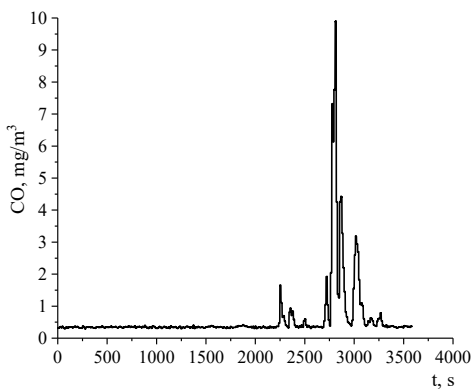

(e)

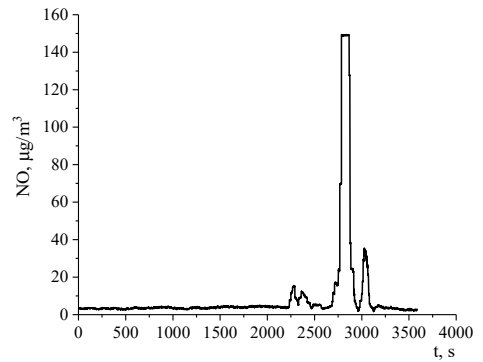

(b)

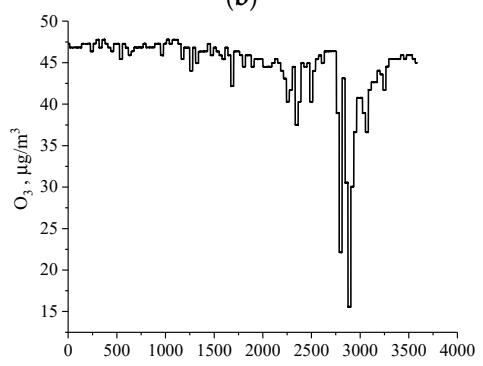

(d)

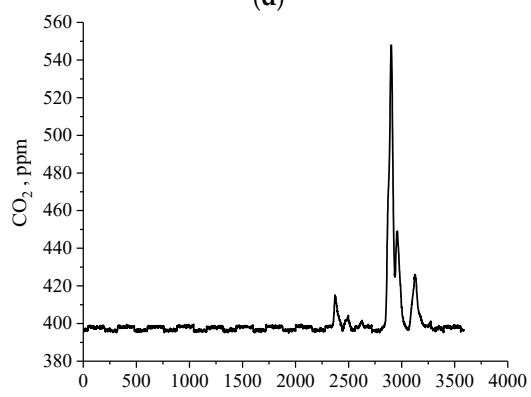

$(\mathbf{f})$

Figure 9. Cont. 


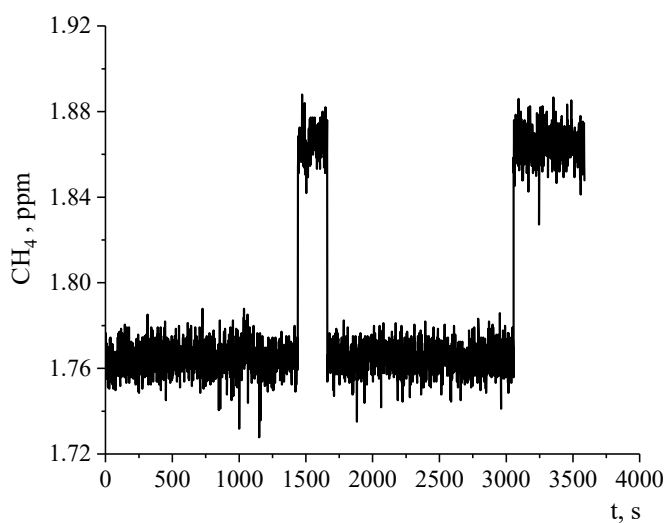

(g)

Figure 9. Variations in the concentrations of atmospheric gases during the model steppe fire in $2011:(\mathbf{a}) \mathrm{NO}_{2} ;(\mathbf{b}) \mathrm{NO}$ (c) $\mathrm{SO}_{2} ;(\mathbf{d}) \mathrm{O}_{3}$; (e) $\mathrm{CO} ;(\mathbf{f}) \mathrm{CO}_{2} ;(\mathbf{g}) \mathrm{CH}_{4}$.

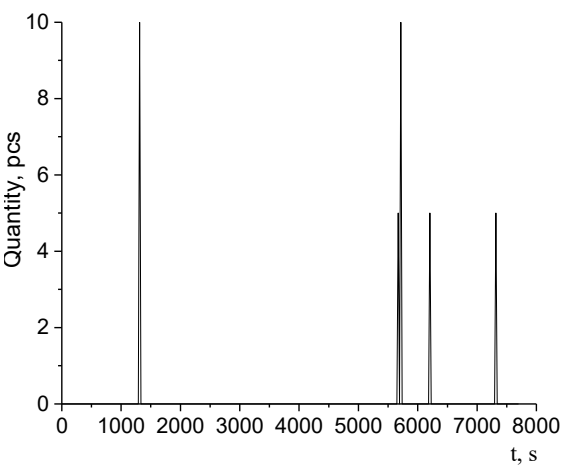

(a)

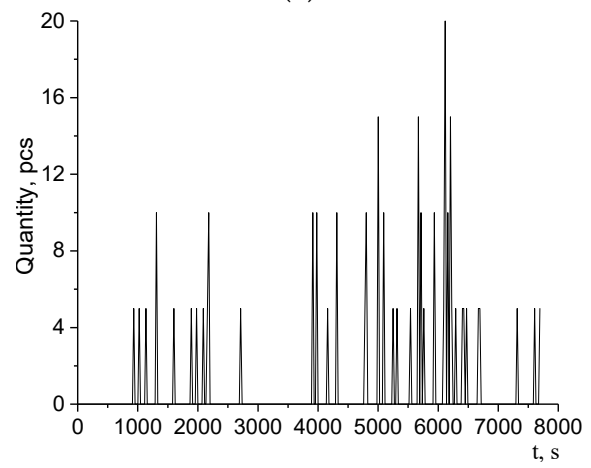

(c)

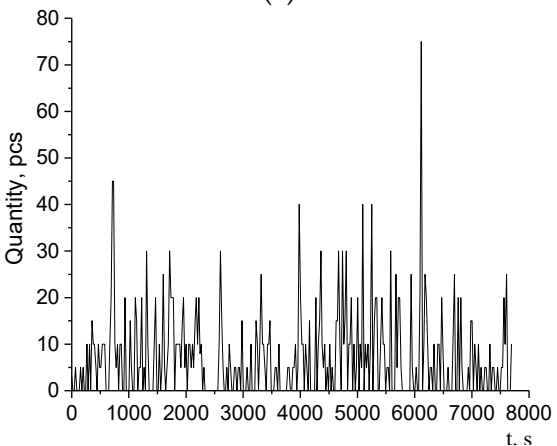

(e)

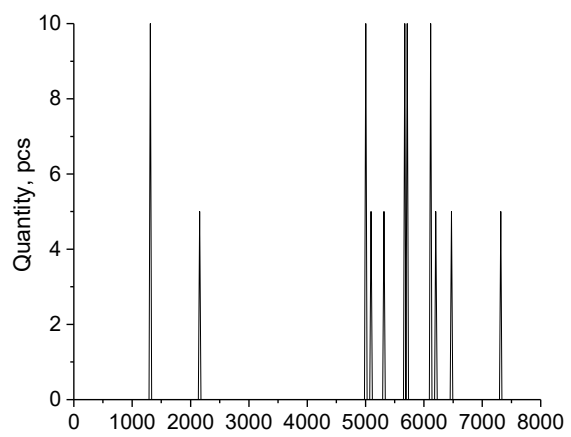

(b)

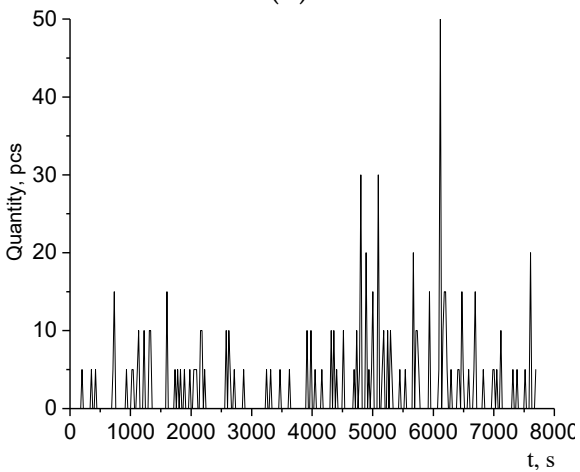

(d)

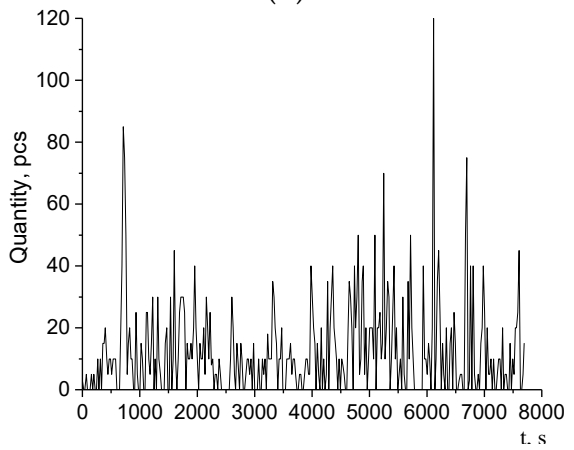

(f)

Figure 10. Cont. 


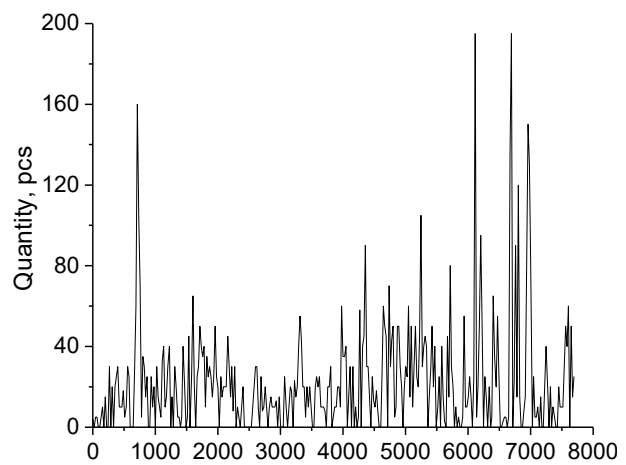

(g)

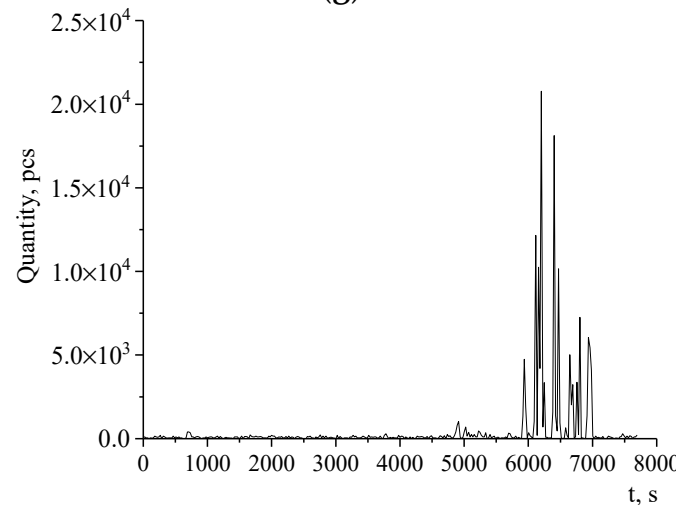

(i)

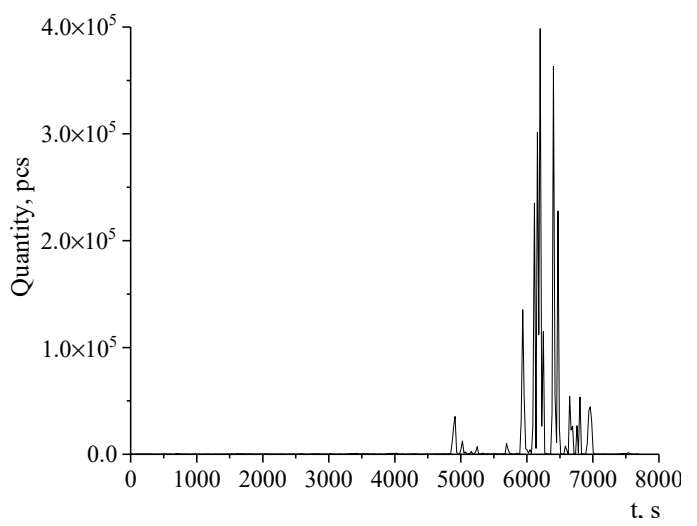

(k)

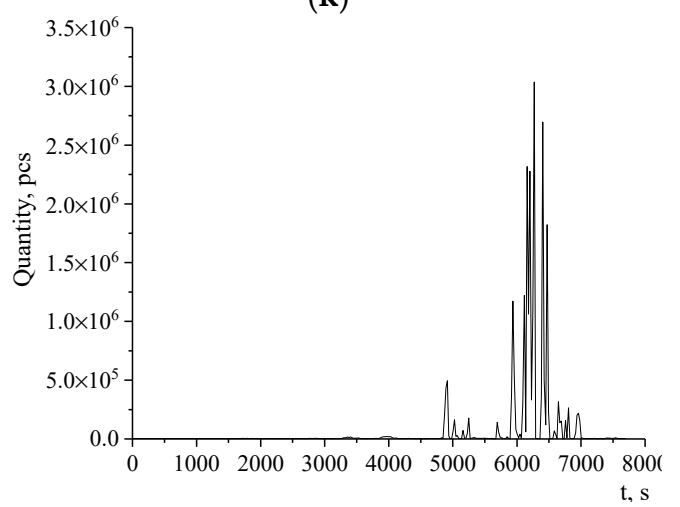

(m)

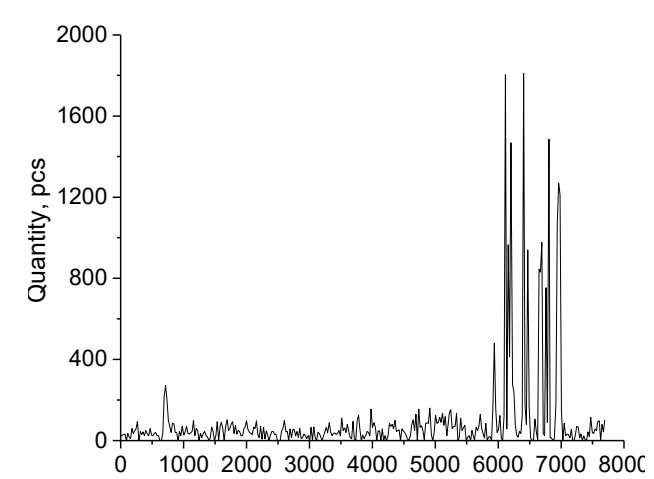

(h)

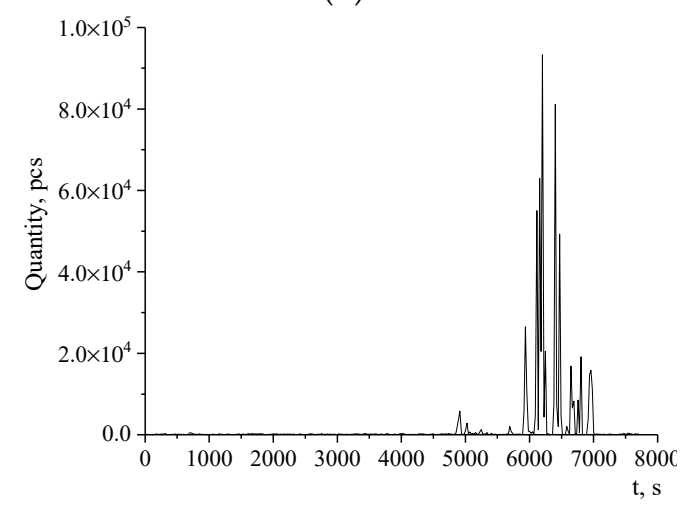

(j)

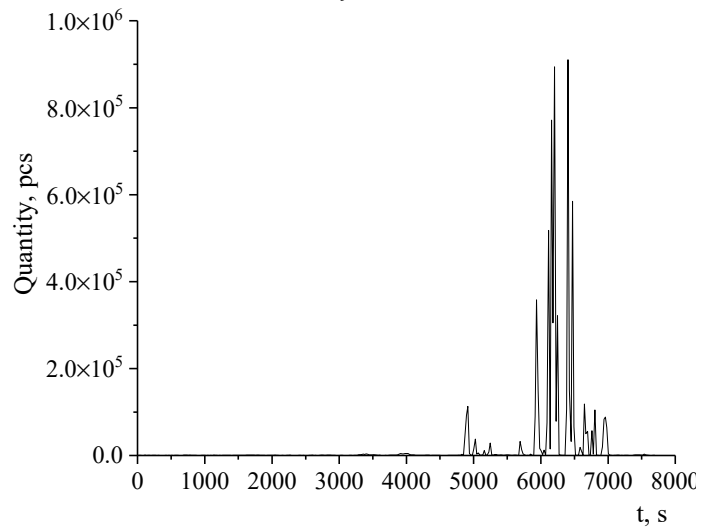

(1)

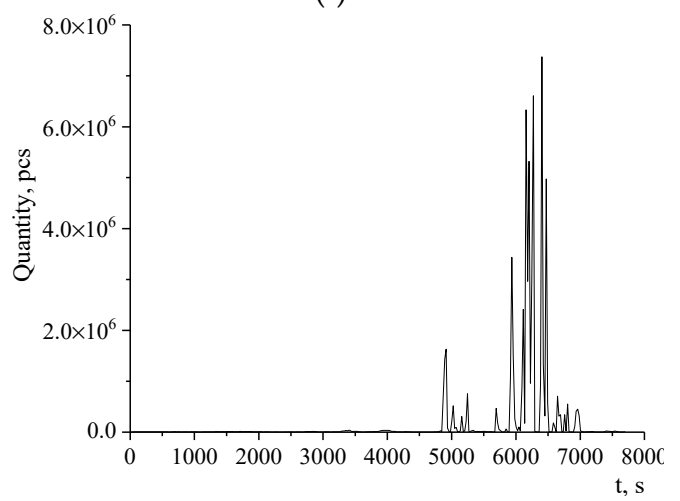

(n)

Figure 10. Cont. 


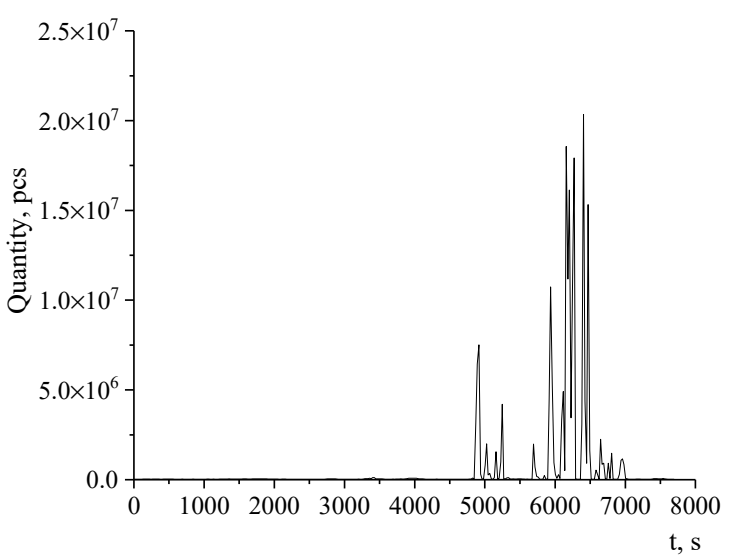

(o)

Figure 10. Variations in the aerosol composition of the atmosphere during the model steppe fire in 2011: (a) $d>20 \mu \mathrm{m}$; (b) $\mathrm{d}>15 \mu \mathrm{m}$; (c) d > $10 \mu \mathrm{m}$; (d) d > $7.5 \mu \mathrm{m}$; (e) d > $5 \mu \mathrm{m}$; (f) d > $4 \mu \mathrm{m}$; (g) d > $3 \mu \mathrm{m}$; (h) d > $2 \mu \mathrm{m}$; (i) d > $1.6 \mu \mathrm{m}$; (j) d > $1 \mu \mathrm{m}$; (k) $\mathrm{d}>0.8 \mu \mathrm{m}$; (1) $\mathrm{d}>0.65 \mu \mathrm{m}$; (m) d $>0.5 \mu \mathrm{m}$; (n) $\mathrm{d}>0.4 \mu \mathrm{m}$; (o) $\mathrm{d}>0.3 \mu \mathrm{m}$.

\section{Conclusions}

1. Even small-scale wildfires result in the rise of air temperature by $2-3^{\circ}$ and a stepwise change in relative air humidity due to active moisture evaporation in front of the burning front and as a result of chemical reactions.

2. Quite large-scale turbulent structures are observed during a seminatural wildfire at the fire front, which do not occur under laboratory conditions and are due to the scale and wind action. The predominance of large-scale turbulence in the flame results in air turbulization in the vicinity of the burning center.

3. High heat release in the burning zone and a developed turbulent structure of the flame cause an increase in the vertical component of the wind velocity and magnification of fluctuations of the air refractive index, which is an indicator of air turbulization not only in the propagation direction of the fire front but also in the close vicinity; this also creates prerequisites for the formation of "own wind" in large-scale fires, which has been first suggested in the work [22].

4. A small-scale wildfire results in an increase in the concentrations of greenhouse and oxidizing gases $\left(\mathrm{NO}_{2}, \mathrm{NO}, \mathrm{SO}_{2}, \mathrm{CO}, \mathrm{CO}_{2}\right.$, and $\left.\mathrm{CH}_{4}\right)$ in its vicinity. The causes of the increase in methane concentration are unclear and require further experimental and theoretical studies.

5. Changes in the aerosol and gas compositions of the atmosphere during a wildfire are recorded with a delay caused by atmospheric transfer processes and can be used in systems for the remote detection of wildfires.

We can finally conclude that large-scale turbulence in a flame and its dissipation result in the formation of atmospheric turbulence and an increase in the vertical component of wind velocity. This, in turn, creates the conditions for formation of the "proper wind", which extraordinarily affects fire spread and intensity. These phenomena obviously affect local weather parameters during large-scale fires, undoubtedly aggravating the consequences of a fire and making it difficult to combat.

We believe the results of this work to be valuable for the mathematical simulation of steppe fires and the development of a large-scale mathematical model capable of taking into account not only thermophysical and chemical processes accompanying combustion but also the effect of a fire on atmospheric processes that determine both weather parameters and transport of aerosols and gases generated during fires. 
Author Contributions: Conceptualization, E.L.; formal analysis, E.L., D.K., M.A., and V.R.; investigation, E.L., D.K., M.A., Y.G., V.T., P.M., Y.L., K.O., K.S., and A.D.; methodology, E.L., D.K., M.A., and V.R.; project administration, D.K.; visualization, M.A., D.K., V.T., and E.L.; writing—original draft preparation, E.L. and D.K.; writing-review and editing, M.A., V.R., D.K., and E.L. All authors have read and agreed to the published version of the manuscript.

Funding: This work was supported by the Russian Science Foundation (project No. 20-71-10068).

Data Availability Statement: The data presented in this study are available on request from the first, and the corresponding author.

Conflicts of Interest: The authors declare no conflict of interest. The founding sponsors had no role in the design of the study; in the collection, analyses, or interpretation of data; in the writing of the manuscript; or in the decision to publish the results.

\section{References}

1. Westerling, A.L.; Hidalgo, H.G.; Cayan, D.R.; Swetnam, T.W. Warming and earlier spring increase western U.S. forest wildfire activity. Science 2006, 313, 940-943. [CrossRef]

2. Wotton, B.M.; Flannigan, M.D.; Marshall, G.A. Potential Climate Change Impacts on Fire Intensity and Wildfire Suppression Thresholds in Canada. Environ. Res. Lett. 2017, 12, 1-12. [CrossRef]

3. Pausas, J.G.; Llovet, J.; Rodrigo, A.; Vallejo, R. Are wildfires a disaster in the Mediterranean basin? A review. Int. J. Wildl. Fire 2008, 17, 713-723. [CrossRef]

4. Larkin, N.K.; Raffuse, S.M.; Strand, T.M. Wildland fire emissions, carbon, and climate: U.S. emissions inventories. For. Ecol. Manag. 2014, 317, 61-69. [CrossRef]

5. Voulgarakis, A.; Field, R.D. Fire Influences on Atmospheric Composition, Air Quality and Climate. Curr. Pollut. Rep. 2015, 1, 70-81. [CrossRef]

6. Vinogradova, A.A.; Smirnov, N.S.; Korotkov, V.N.; Romanovskaya, A.A. Forest fires in Siberia and the Far East: Emissions and atmospheric transport of black carbon to the Arctic. Atmos. Ocean. Opt. 2015, 28, 512-520. [CrossRef]

7. Sitnov, S.A.; Mokhov, I.I.; Dzhola, A.V. The confluence of Siberian fires on the content of carbon monoxide in the atmosphere over the European part of Russia in the summer of 2016. Atmos. Ocean. Opt. 2017, 30, 146-152.

8. Popovicheva, O.B.; Kozlov, V.S.; Rakhimov, R.F.; Shmargunov, V.P.; Kireyeva, Y.D.; Persiantseva, N.M.; Timofeyev, M.A.; Engling, G.; Elephteriadis, K.; Diapouli, L.; et al. Optical-microphysical and physicochemical characteristics of combustion fumes of Siberian biomass: Experiments in an aerosol chamber. Atmos. Ocean. Opt. 2016, 29, 323-331. [CrossRef]

9. Alves, N.D.; Brito, J.; Caumo, S.; Arana, A.; Hacon, S.; Artaxo, P.; Hillamo, R.; Teinilä, K.; Medeiros, S.; Vasconcellos, P. Biomass burning in the Amazon region: Aerosol source apportionment and associated health risk assessment. Atmos. Environ. 2015, 120, 277-285. [CrossRef]

10. Pani, S.K.; Wang, S.; Lin, N.; Chantara, S.; Lee, C.; Thepnuan, D. Black carbon over an urban atmosphere in northern peninsular Southeast Asia: Characteristics, source apportionment, and associated health risks. Environ. Pollut. 2019, 259, 113871. [CrossRef]

11. Mkoma, S.L.; Kawamura, K.; Fu, P.Q. Contributions of biomass/biofuel burning to organic aerosols and particulate matter in Tanzania, East Africa, based on analyses of ionic species, organic and elemental carbon, levoglucosan and mannosan. Atmos. Chem. Phys. 2013, 13, 10325-10338. [CrossRef]

12. Yokelson, R.J.; Burling, I.R.; Urbanski, S.P.; Atlas, E.L.; Adachi, K.; Buseck, P.R.; Wiedinmyer, C.; Akagi, S.K.; Toohey, D.W.; Wold, C.E. Trace gas and particle emissions from open biomass burning in Mexico. Atmos. Chem. Phys. 2011, 11, 6787-6808. [CrossRef]

13. Santín, C.; Doerr, S.; Kane, E.; Masiello, C.; Ohlson, M.; Rosa, J.M.; Preston, C.; Dittmar, T. Towards a global assessment of pyrogenic carbon from vegetation fires. Glob. Chang. Biol. 2016, 22, 76-91. [CrossRef] [PubMed]

14. Sommers, W.; Loehman, R.; Hardy, C.C. Wildland fire emissions, carbon, and climate: Science overview and knowledge needs. For. Ecol. Manag. 2014, 317, 1-8. [CrossRef]

15. Adams, J.S.; Williams, D.W.; Tregellas-Williams, J. Air velocity, temperature, and radiant-heat measurements within and around a large free-burning fire. Proc. Combust. Inst. 1973, 14, 1045-1052. [CrossRef]

16. Albini, F.A. Spot Fire Distance from Burning Trees-A Predictive Model; USDA Forest Service, Intermountain Forest and Range Experiment Station INT-GTR-56: Ogden, UT, USA, 1979; p. 73.

17. Cohen, J.D. A Site-Specific Approach for Assessing the Fire Risk to Structures at the Wildland Urban Interface. Fire and the Environment: Ecological and Cultural Perspectives. In Proceedings of the An International Symposium SE-69, Ashville, NC, USA, 20-24 March 1991; pp. 252-256.

18. Muraszew, A.; Fedele, J.F. Statistical Model for Spot Fire Spread; The Aerospace Corporation: Los Angeles, CA, USA, 1976.

19. Taylor, R.J.; Evans, S.T.; King, N.K.; Stephens, E.T.; Packham, D.R.; Vines, R.G. Convective activity above a large-scale bushfire. J. Appl. Meteorol. Climatol 1973, 12, 1144-1150. [CrossRef]

20. Quintiere, J.G. Canadian mass fire experiment. J. Fire Prot. Engr. 1993, 5, 67-78. [CrossRef]

21. Grishin, A.M.; Yakimov, A.S. Mathematical modeling of the initiation and spread of peat fires. J. Eng. Phys. Thermophys. 2011, 84, 1047-1057. [CrossRef] 
22. Grishin, A.M. Mathematical Modeling of Forest Fires and New Methods of Fighting Them; Publishing House of the Tomsk State University: Tomsk, Russia, 1997.

23. Stocks, B.J.; Alexander, M.E.; Wotton, B.M.; Stefner, C.N.; Flannigan, M.D.; Taylor, S.W.; Lavoie, N.; Mason, J.A.; Hartley, G.R.; Maffey, M.E.; et al. Crown fire behaviour in a northern jack pine-Black spruce forest. Can. J. For. Res. 2004, 34, 1548-1560. [CrossRef]

24. Goldammer, J.G.; Furyaev, V. (Eds.) Fire in Ecosystems of Boreal Eurasia, Fire in Ecosystems of Boreal Eurasia; Springer: Dordrecht, The Netherlands, 1996.

25. Andersen, H.E.; McGaughey, R.J.; Reutebuch, S.E. Estimating forest canopy fuel parameters using LIDAR data. Remote Sens. Environ. 2005, 94, 441-449. [CrossRef]

26. Boulet, P.; Parent, G.; Collin, A.; Acem, Z.; Porterie, B.; Clerc, J.P.; Consalvi, J.L.; Kaiss, A. Spectral emission of flames from laboratory-scale vegetation fires. Int. J. Wildl. Fire 2009, 18, 875-884. [CrossRef]

27. Gould, J.; McCaw, W.; Cheney, N.; Ellis, P.; Knight, I.; Sullivan, A. Project vesta: Fire in dry eucalypt forest. Int. J. Wildl. Fire 2019, $18,875-884$.

28. Hinzman, L.D.; Fukuda, M.; Sandberg, D.V.; Chapin, F.S.; Dash, D. FROSTFIRE: An experimental approach to predicting the climate feedbacks from the changing boreal fire regime. J. Geophys. Res. D Atmos. 2003, 108, 1-6. [CrossRef]

29. Kochanski, A.K.; Jenkins, M.A.; Mandel, J.; Beezley, J.D.; Clements, C.B.; Krueger, S. Evaluation of WRF-SFIRE performance with field observations from the FireFlux experiment. Geosci. Model. Dev. 2013, 6, 1109-1126. [CrossRef]

30. Pastor, E.; Àgueda, A.; Andrade-Cetto, J.; Muñoz, M.; Pérez, Y.; Planas, E. Computing the rate of spread of linear flame fronts by thermal image processing. Fire Saf. J. 2006, 41, 569-579. [CrossRef]

31. Prichard, S.; Larkin, N.S.; Ottmar, R.; French, N.H.F.; Baker, K.; Brown, T.; Clements, C.; Dickinson, M.; Hudak, A.; Kochanski, A.; et al. The Fire and Smoke Model Evaluation Experiment-A plan for integrated, large fire-atmosphere field campaigns. Atmosphere 2019, 10, 66. [CrossRef]

32. Garcia-Hurtado, E.; Pey, J.; Baeza, M.J.; Carrara, A.; Llovet, J.; Querol, X.; Alastuey, A.; Vallejo, V.R. Carbon emissions in Mediterranean shrubland wildfires: An experimental approach. Atmos. Environ. 2013, 69, 86-93. [CrossRef]

33. Howard, D.; Macsween, K.; Edwards, G.C.; Desservettaz, M.; Guérette, E.A.; Paton-Walsh, C.; Surawski, N.C.; Sullivan, A.L.; Weston, C.; Volkova, L.; et al. Investigation of mercury emissions from burning of Australian eucalypt forest surface fuels using a combustion wind tunnel and field observations. Atmos. Environ. 2019, 202, 17-27. [CrossRef]

34. Solomos, S.; Gialitaki, A.; Marinou, E.; Proestakis, E.; Amiridis, V.; Baars, H.; Komppula, M.; Ansmann, A. Modeling and remote sensing of an indirect Pyro-Cb formation and biomass transport from Portugal wildfires towards Europe. Atmos. Environ. 2019, 206, 303-315. [CrossRef]

35. Larkin, N.K.; O’Neill, S.M.; Solomon, R.; Raffuse, S.; Strand, T.; Sullivan, D.C.; Krull, C.; Rorig, M.; Peterson, J.; Ferguson, S.A. The BlueSky smoke modeling framework. Int. J. Wildl. Fire 2009, 18, 906-920. [CrossRef]

36. Seiler, W.; Crutzen, P.J. Estimates of gross and net fluxes of carbon between the biosphere and the atmosphere from biomass burning. Clim. Chang. 1980, 2, 207-247. [CrossRef]

37. Urbanski, S.P.; Hao, W.M.; Nordgren, B. The wildland fire emission inventory: Western United States emission estimates and an evaluation of uncertainty. Atmos. Chem. Phys. 2011, 11, 12973-13000. [CrossRef]

38. Liu, Y.; Qu, J.J.; Wang, W.; Hao, X. Estimates of Wildland Fire Emissions. In Remote Sensing Modeling and Applications to Wildland Fires; Qu, J.J., Sommers, W., Yang, R., Riebau, A., Kafatos, M., Eds.; Springer: Berlin/Heidelberg, Germany, 2013; Volume 9, pp. 117-133.

39. Colarco, P.R.; Schoeberl, M.R.; Doddridge, B.G.; Marufu, L.T.; Torres, O.; Welton, E.J. Transport of smoke from Canadian forest fires to the surface near Washington, D.C.: Injection height, entrainment, and optical properties. J. Geophys. Res. Atmos. 2004, 109, 1-12. [CrossRef]

40. Liu, Y. Sensitivity of air quality simulation to smoke plume rise. J. Appl. Remote Sens. 2008, 2, 1-12. [CrossRef]

41. Goodrick, S.L.; Achtemeier, G.L.; Larkin, N.K.; Liu, Y.; Strand, T.M. Modelling smoke transport from wildland fires: A review. Int. J. Wildl. Fire 2013, 22, 83-94. [CrossRef]

42. Grishin, A.M.; Filkov, A.I.; Loboda, Y.L.; Kuznetsov, V.T.; Reyno, V.V.; Rudi, Y.A. Physical modeling of steppe fires in natural conditions. J. Fire Saf. 2010, 2, 100-105.

43. Arshinov, M.Y.; Belan, B.D.; Davydov, D.K.; Ivlev, G.A.; Kozlov, A.V.; Pestunov, D.A.; Pokrovskiy, Y.V.; Tolmachev, G.N.; Fofonov, A.V. Posts for monitoring greenhouse and oxidizing gases. Atmos. Ocean. Opt. 2007, 20, 53-61.

44. Institute of Monitoring of Climatic and Ecological Systems of the Siberian Branch of the Russian Academy of Sciences (IMCES SB RAS). Available online: http:/ / www.imces.ru/index.php?rm=news\&action=view\&id=402 (accessed on 25 December 2020).

45. Loboda, E.L.; Reino, V.V.; Agafontsev, M.V. Choice of a spectral range for measuring temperature fields in a flame and recording high-temperature objects screened by the flame using IR diagnostic methods. Russ. Phys. J. 2015, 58, 278-282. [CrossRef]

46. Grishin, A.M.; Filkov, A.I.; Loboda, E.L.; Reyno, V.V.; Kozlov, A.V.; Kuznetsov, V.T.; Kasymov, D.P.; Andreyuk, S.M.; Ivanov, A.I.; Stolyarchuk, N.D. A field experiment on grass fire effects on wooden constructions and peat layer ignition. Int. J. Wildl. Fire 2014, 23, 445-449. [CrossRef]

47. Grishin, A.M.; Filkov, A.I.; Loboda, E.L.; Reyno, V.V.; Kuznetsov, V.T. Field experimental studies of the effects of field fires on wooden fencing and peat. J. Fire Saf. 2013, 3, 52-58. 
48. Grishin, A.M.; Filkov, A.I.; Loboda, E.L.; Reyno, V.V.; Rudi, Y.A.; Kuznetsov, V.T.; Karavayev, V.V. Experimental studies of the occurrence and spread of a steppe fire in natural conditions. Tomsk State Univ. J. Math. Mech. 2011, 2, 91-102.

49. Loboda, E.L.; Kasymov, D.P.; Filkov, A.I.; Reyno, V.V.; Agafontsev, M.V. Some Aspects of Research in the Field and Laboratory Conditions of Wildfires Using Thermography. In Proceedings of the XXX International Research and Practical Conference «Current Problems of Fire Safety», Moscow, Russia, 4-5 July 2017; pp. 295-300.

50. Loboda, E.L.; Matvienko, O.V.; Vavilov, V.P.; Reyno, V.V. Infrared thermographic evaluation of flame turbulence scale. Infrared Phys. Technol. 2015, 72, 1-7. [CrossRef]

51. Shchelkin, K.I. Selected Works; Loboiko, B.G., Ed.; VNIITF Publisher: Snezhinsk, Russia, 2011; p. 268.

52. Kochanski, A.K.; Fournier, A.; Mandel, J. Experimental design of a prescribed burn instrumentation. Atmosphere 2018, 9, 296. [CrossRef]

53. Matveev, L.T. General Meteorology Course: Atmospheric Physics; Hydrometeoizdat: Leningrad, USSR, $1984 ;$ p. 738.

54. Zuev, V.E. Propagation of Visible and Infrared Waves in the Atmosphere; Sovetskoe Radio: Moscow, Russia, 1970.

55. Loboda, E.L.; Anufriev, I.S.; Agafontsev, M.V.; Kopyev, E.P.; Shadrin, E.Y.; Reyno, V.V.; Vavilov, V.P.; Lutsenko, A.V. Evaluating characteristics of turbulent flames by using IR thermography and PIV. Infrared Phys. Technol. 2018, 92, 240-243. [CrossRef] 